\title{
PEMANFAATAN TEKNOLOGI UNTUK PENINGKATAN LAYANAN BPJS PADA PERBANKAN SYARIAH
}

\author{
Dunyati Ilmiah ${ }^{1}$, Ageng Asmara Sani ${ }^{2}$, Muhammad Galih Wonoseto ${ }^{3}$ \\ ${ }^{1,2}$ Universitas Alma Ata Yogyakarta \\ ${ }^{3}$ UIN Sunan Kalijaga Yogyakarta
}

Email: dunyatiilmy@almaata.ac.id, agengasmara@almaata.ac.id, muhammad.wonoseto@uin-suka.ac.id

\begin{abstract}
This research measures and analyzes the use of technology to improve BPJS services in Islamic banking using the Survey on Financial Inclusion and Access SOFIA data. Data was collected in 2017 in four provinces, namely East Java, West Nusa Tenggara, East Nusa Tenggara, and South Sulawesi with a total number of respondents 19,634. The findings in this study reveal that $98.36 \%$ of people pay BPJS using the cash method and 1.64\% of people use technology. From the data above, it can be concluded that the people in the four provinces are very minimal related to financial inclusion, people prefer to make cash payments rather than using payment service facilities in Islamic banking. The results of this study attracted the attention of policymakers to improve information and education related to financial inclusion
\end{abstract}

Keywords: BPJS, Financial Literacy, Technology, Syariah Banking

Abstrak : Penelitian ini bertujuan untuk mengukur dan menganalisis pemanfaatan teknologi dalam meningkatan layanan BPJS di perbankan syariah dengan menggunakan data Survey on Financial Inclusion and Access SOFIA. Data dihimpun pada tahun 2017 di empat provinsi yaitu Jawa Timur, Nusa Tenggara Barat, Nusa Tenggara Timur, dan Sulawesi Selatan dengan jumlah responden 19.634. Temuan dalam penelitian ini mengungkapkan bahwa 98,36\% masyarakat membayar BPJS dengan metode cash dan 1,64\% masyarakat yang memanfaatkan teknologi. Dari data di atas disimpulkan bahwa masyarakat di empat provinsi tersebut sangat minim terkait inklusi keuangan, masyarakat lebih suka melakukan pembayaran secara cash dari pada menggunakan fasilitas jasa pembayaran di perbankan syariah. Hasil penelitian ini menarik perhatian pemangku kebijakan untuk meningkatkan informasi maupun edukasi terkait inklusi keuangan

Kata kunci: BPJS, Literasi Keuangan, Teknologi, Perbankan Syariah.

\section{A. PENDAHULUAN}

Pengembangan keuangan syariah perlu mengoptimalkan seluruh potensi keuangan syariah salah satunya di industri keuangan non-bank. Industri keuangan syariah harus menjadi industri keuangan inklusif dan mampu memenuhi kebutuhan pembiayaan dalam skala kecil dan menengah hingga skala pembiayaan yang besar untuk menunjang pembangunan nasional. Di samping itu, keuangan syariah juga dipercaya akan berkembang lebih cepat dan berkelanjutan bila didukung dengan integrasi dan sinergi antara sektor riil, sektor keuangan, dan sektor religius/sosial sehingga ketiga sektor tersebut dapat tumbuh lebih cepat secara bersama-sama. Sejalan dengan itu maka kemudahan akses masyarakat terhadap produk, kualitas pelayanan, serta infrastruktur di industri keuangan syariah juga ditingkatkan. ${ }^{1}$

Selain penggunaan website, untuk meningkatkan jangkauan produk keuangan

hlm. 1-82.

${ }^{1}$ OJK, “Roadmap Pengembangan Keuangan Syariah 2017-2019,” Otoritas Jasa Keuangan (2017), 
kepada masyarakat di daerah atau mempermudah masyarakat daerah untuk mengakses produk keuangan syariah, platform financial technology (fintech) dapat digunakan, yaitu sedapat mungkin menggunakan aplikasi yang dapat diinstal di dalam smartphone ataupun komputer. Hal ini mengingat saat ini hampir setiap orang memiliki akses internet baik melalui smartphone ataupun jaringan komputer. Berkenaan dengan hal itu, OJK perlu memperkuat kebijakan terkait pengembangan teknologi informasi guna meningkatkan akses terhadap kebutuhan keuangan syariah, baik dengan menggunakan web-base maupun platform fintech. Dengan demikian, dalam memenuhi kebutuhan akan layanan keuangan syariah masyarakat tidak dihadapkan dengan masalah jarak dan waktu yang selama ini menjadi kendala dalam mengakses keuangan syariah. ${ }^{2}$

Industri keuangan Non-bank (IKNB) syariah yang diawasi oleh OJK mencakup berbagai sektor, yaitu perusahaan perasuransian syariah, dana pensiun syariah, lembaga pembiayaan syariah, dan lembaga keuangan syariah khusus serta lembaga keuangan mikro (LKM) syariah. Perusahaan perasuransian syariah mencakup perusahaan asuransi jiwa syariah, perusahaan asuransi umum syariah dan perusahaan reasuransi syariah. Lembaga pembiayaan syariah mencakup perusahaan pembiayaan syariah, perusahaan modal ventura syariah dan perusahaan pembiayaan infrastruktur. Selain itu, industri yang tercakup dalam lembaga jasa keuangan syariah khusus sampai dengan akhir tahun 2016 terdiri atas perusahaan penjaminan syariah, lembaga pembiayaan ekspor Indonesia, dan perusahaan pergadaian syariah. ${ }^{3}$

Perkembangan industri keuangan non-bank syariah menunjukkan perkembangan yang positif sebagaimana dapat dilihat dari perkembangan aset, pelaku, dan regulasi. Grafik berikut menunjukkan bahwa perkembangan aset IKNB syariah dalam kurun lima tahun terakhir secara umum menunjukkan peningkatan, dari sebesar Rp41.808 miliar pada tahun 2012 meningkat menjadi Rp88.674 miliar pada tahun 2016. Peningkatan rata-rata per tahun menunjukkan sebesar $43,77 \%{ }^{4}$

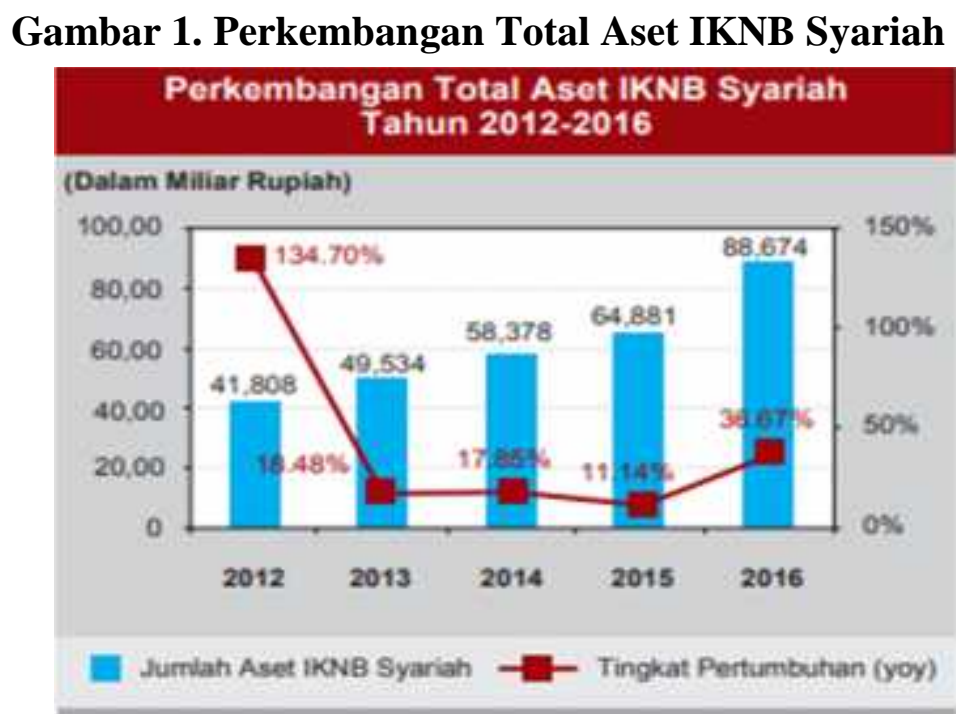

Sumber: Roadmap OJK, 2017
${ }^{2}$ Ibid.
${ }^{3}$ Ibid.
${ }^{4}$ Ibid. 
Asuransi di Indonesia, disebut BPJS Kesehatan, diterapkan pada awal 2014. Sistem asuransi ini mampu meningkatkan kepuasan dan loyalitas pasien. Sebelum adanya BPJS kesehatan, banyak orang tidak bisa berobat karena kurangnya dana. Dengan adanya BPJS, masyarakat bisa berobat gratis, meski harus memberikan kontribusi bulanan. Sistem asuransi dapat meningkatkan kepuasan dan loyalitas masyarakat jika iuran BPJS yang dibayarkan perbulan terjangkau, adanya kejelasan hak dan kewajiban peserta kesehatan BPJS, masyarakat memiliki kebebasan untuk memilih rumah sakit, dan adanya kemudahan dalam menggunakan kartu BPJS. ${ }^{5}$ BPJS menggunakan asas gotong royong dengan prinsip asuransi sosial yang mirip pada akad tabarru' yang digunakan dalam asuransi syariah. ${ }^{6}$

Penelitian yang dilakukan oleh Itang. Pelayanan kesehatan BPJS mempunyai sasaran dalam pelaksanaan akan adanya sustainibilitas operasional dengan memberi manfaat kepada semua yang terlibat dalam BPJS, pemenuhan kebutuhan medik peserta, dan kehatihatian, serta transparansi dalam pengelolaan keuangan BPJS. Perlu perhatian lebih mendalam dalam pelaksanaan terhadap sistem pelayanan kesehatan (health care delivery sistem), sistem pembayaran (health care payment sistem) dan sistem mutu pelayanan kesehatan (health care quality sistem $)^{7}$

Pelayanan publik harus dapat menjawab tuntutan masyarakat sekaligus tantangan jaman. Perubahan pelayanan yang dipengaruhi oleh tuntutan masyarakat, diawali oleh perubahan sistem sosial yang terjadi di masyarakat itu sendiri. Sehingga, berdampak pada sistem atau tata kelola pelayanan publik. Dengan kata lain tranformasi pelayanan publik bukan hanya mampu mengefisienkan institusi secara internal namun mampu memberikan kepuasan pada publik sebagai pihak eksternal melalui layanan publik yang prima. ${ }^{8}$

Inklusi keuangan adalah sebuah proses untuk menjamin kemudahan akses, ketersedian dan penggunaan sistem keuangan formal oleh seluruh pelaku ekonomi. Inklusi keuangan menyediakan jasa keuangan seperti tabungan, kredit, asuransi, dan pembayaran pada tingkat harga yang mampu dibayar oleh seluruh pelaku ekonomi, terutama pelaku ekonomi berpendapatan rendah. ${ }^{9}$ Penelitian yang dilakukan oleh Annamaria ${ }^{10}$ menyatakan bahwa literasi keuangan terdiri dari sejumlah kemampuan dan pengetahuan mengenai keuangan yang dimiliki oleh seseorang untuk mampu mengelola atau menggunakan sejumlah uang untuk meningkatkan taraf hidupnya dan bertujuan untuk mencapai kesejahteraan.

Indeks inklusi keuangan perbankan dan BPJS Kesehatan jauh meninggalkan indeks inklusi keuangan untuk sektor-sektor lainnya pada tahun yang sama. Perasuransian memiliki

\footnotetext{
${ }^{5}$ Alifah Ratnawati, Widiyanto bin Mislan Cokrohadisumarto, and Noor Kholis, "Improving the Satisfaction and Loyalty of BPJS Healthcare in Indonesia: A Sharia Perspective," Journal of Islamic Marketing (2020)

${ }^{6}$ Cahur Usman, “Analisis Pengelolaan BPJS Dalam Perspektif Ekonomi Islam ( Studi Kasus BPJS Kesehatan Makassar )” (2016).

7Itang Itang, "BPJS Kesehatan Dalam Perspektif Ekonomi Syariah,” AHKAM : Jurnal Ilmu Syariah Vol.15, no. 2 (2015), hlm. 153-162.

${ }^{8}$ Krishno Hadi, Listiana Asworo, and Iradhad Taqwa, "Inovasi Dialogis: Menuju Transformasi Pelayanan Publik Yang Partisipatif (Kajian Sistem Pelayanan Malang Online)," Journal of Government and Civil Society 4, no. 1 (2020), hlm. 115.

${ }^{9}$ Celestine Sunday Okaro, "Financial Inclusion and Nigerian Economy ( 1990-2015 )," Journal of Policy and Development Studies Vol.10, no. 4 (2016), hlm. 50-65.

${ }^{10}$ Annamaria Lusardi and Olivia S. Mitchell, "The Economic Importance of Financial Literacy: Theory and Evidence," Journal of Economic Literature Vol.52, no. 1 (2014), hlm. 5-44.
} 
indeks inklusi keuangan sebesar 12,08 persen pada tahun 2016, meningkat dari 11,81 persen pada tahun 2013. Kemudian indeks inklusi keuangan untuk lembaga pembiayaan adalah 11,85 persen pada tahun 2016, meningkat dari 6,33 persen pada tahun 2013. Pasar modal merupakan sektor yang mempunyai indeks inklusi keuangan terendah, yaitu hanya 1,25 persen pada tahun 2016, sedikit meningkat dibandingkan kondisi 2013 yang sebesar 0,11 persen. Adapun sektor dana pensiun, pegadaian, dan BPJS Ketenagakerjaan memiliki indeks inklusi keuangan yang tidak seburuk pasar modal, namun masih jauh lebih rendah jika dibandingkan dengan perbankan dan BPJS Kesehatan. ${ }^{11}$

Teknologi informasi sangat besar pengaruhnya, bila dapat dimanfaatkan dengan semaksimal mungkin. Penggunaan teknologi informasi dapat meningkatkan efektivitas dan efisiensi dalam melakukan sebuah proses kegiatan lebih cepat dicapai. Informasi yang lebih cepat dicapai dan berkualitas menjadi harapan bahwasannya proses pelayanan publik dapat ditingkatkan termasuk juga dalam pelayanan kesehatan. ${ }^{12}$ Perkembangan teknologi informasi saat ini banyak memberikan kemudahan pada berbagai aspek kegiatan perusahaan. Teknologi informasi merupakan bagian dari sistem informasi dan teknologi informasi merujuk pada teknologi yang digunakan dalam menyampaikan maupun mengolah informasi. Teknologi informasi adalah suatu teknologi yang berhubungan dengan pengolahan data menjadi informasi dan proses penyaluran data atau informasi dalam batasan ruang dan waktu. Teknologi ini dapat dimanfaatkan untuk pengembangan sistem pencatatan dan pengelolahan data. Penggunaan teknologi tidak luput dari perhatian BPJS Ketenagakerjaan, aplikasi berbasis website pun dibuat oleh BPJS Ketenagakerjaan untuk mempermudah dan mempercepat layanan kepada pelanggan. ${ }^{13}$

Literasi keuangan adalah mencakup kemampuan untuk membedakan pilihan keuangan, mambahas uang dan masalah keuangan tanpa ketidaknyamanan, merencanakan masa depan, dan menanggapi kompeten untuk peristiwa kehidupan yang mempengaruhi keputusan keuangan seharihari, termasuk peristiwa di ekonomi secara umum. Literasi keuangan terjadi manakala seorang individu memiliki sekumpulan keahlian dan kemampuan yang dapat memanfaatkan sumber daya yang ada untuk mencapai tujuan. ${ }^{14}$

Jika dilihat literasi per sektor industri keuangan syariah, tingkat pemahaman dan pemanfaatan masyarakat di sektor perbankan syariah paling tinggi dibandingkan dengan sektor pasar modal syariah dan IKNB syariah, yang ditunjukkan oleh indeks literasi sebesar 6,63\% dan indeks inklusi sebesar 9.61\%. Sektor pasar modal syariah memiliki tingkat literasi dan inklusi yang paling rendah, yaitu $0,02 \%$ untuk literasi dan $0,01 \%$ untuk inklusi. Sementara indeks literasi IKNB syariah sebesar 2,51\% untuk perasuransian, 1,63\% untuk

\footnotetext{
${ }^{11}$ Roberto Akyuwen and Caroline Mangowal, "Komparasi Peningkatan Inklusi Keuangan Dan Indikator Pembangunan Di Indonesia," Modus Vol.30(1), no. 1 (2018), hlm. 96-109.

${ }^{12}$ Wiebi Winarto, Mega Tri Wijayanti, and Lukita Ummahati, "Inovasi Pelayanan Kesehatan Berbasis Elektronik Melalui Sistem Informasi Kesehatan Nasional Online Dan Primary Care BPJS Di Dinas Kesehatan Kota Malang," Prosiding Simposium Nasional (2020), hlm. 493-511.

${ }^{13}$ Sasongko Budi Laksono, "Analisis Efektivitas Dan Efisiensi Pelaporan Tenaga Kerja Dengan Menggunakan Sistem Manual Dan Sistem Online (Studi Kasus PJS Ketenagakerjaan Cabang Gresik)” (2019), hlm.40-50.

${ }^{14}$ Ageng Asmara Sani, Ragil Satria Wicaksana, and Dunyati Ilmiah, "Implikasi Adiba Msme Sebagai Instrumen Channeling Masyarakat Umkm Dalam Menggunakan Layanan Lembaga Keuangan Syariah," Jurnal Tabarru': Islamic Banking and Finance Vol.2, no. 2 (2019), hlm. 38-49.
} 
pegadaian, 0,19\% untuk lembaga pembiayaan, dan $0 \%$ untuk dana pensiun. Tingkat inklusi produk IKNB syariah secara umum di bawah tingkat literasi, kecuali tingkat inklusi lembaga pembiayaan yang lebih tinggi dari tingkat literasinya. Adapun indeks inklusi keuangan pada sektor IKNB syariah adalah 1,92\% untuk asuransi, 0,71\% untuk pegadaian, 0,24\% untuk pembiayaan. Indeks literasi keuangan syariah dan indeks inklusi keuangan syariah per sektor industri digambarkan pada grafik berikut ini:

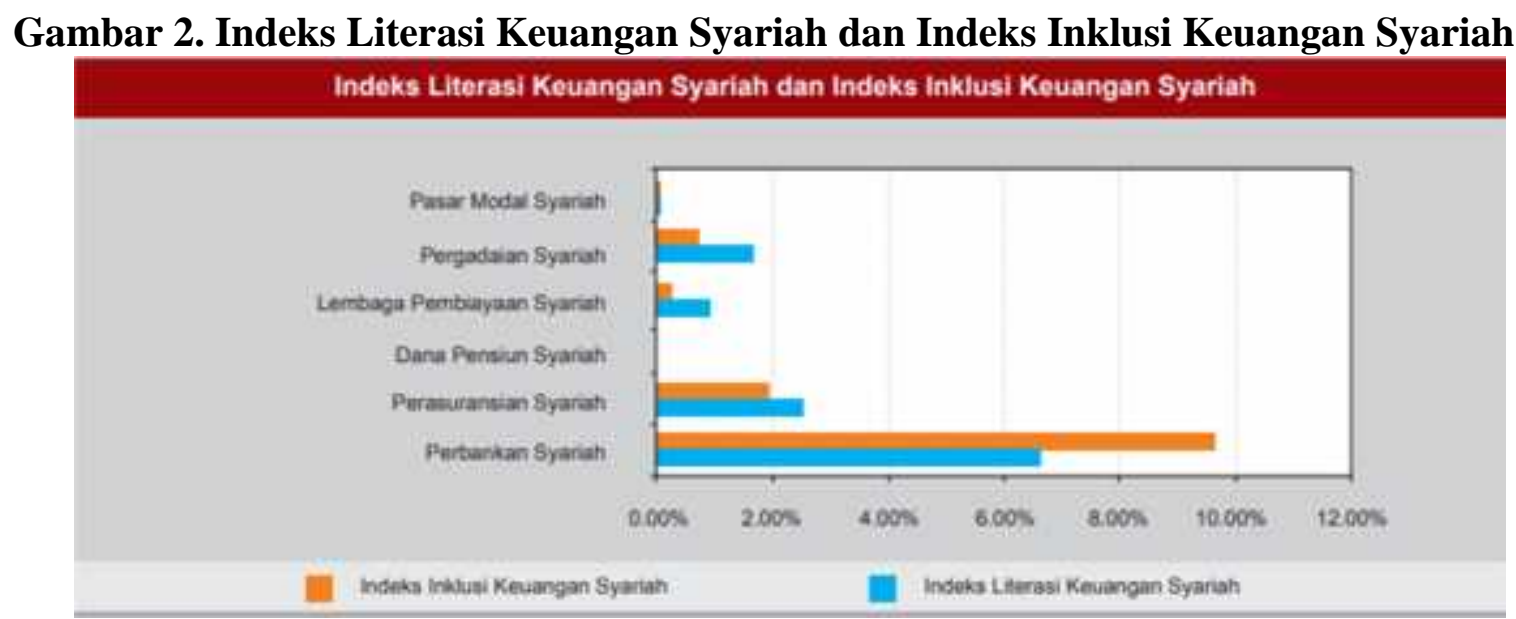

Sumber : Roadmap OJK, 2017

Jaminan Kesehatan Nasional ( JKN) yang diwujudkan dalam bentuk Badan Penyelenggara Jaminan Sosial Kesehatan (BPJSK) mendapat sambutan besar dari masyarakat Indonesia. Sampai pada 31 Desember 2017 jumlah peserta JKN-KIS sudah mencapai 187.982.949, artinya jumlah masyarakat yang telah mengikuti Program JKN-KIS hampir mencapai 72,9\% dari jumlah penduduk Indonesia. Hal itu selaras dengan arah kebijakan dan strategi nasional dalam Rencana Pembangunan Jangka Menengah Nasional (RPJMN) Tahun 2019, disebutkan terdapat sasaran kuantitatif terkait Program Jaminan Kesehatan NasionalKartu Indonesia Sehat (JKN-KIS) yaitu meningkatnya persentase penduduk yang menjadi peserta Jaminan Kesehatan melalui Sistem Jaminan Sosial Nasional (SJSN) Bidang Kesehatan, minimal mencapai 95\% pada tahun 2019 (https://bpjskesehatan.go.id/ bpjs/ index.php/ post/ read/ 2018/ 639/ Jaminan-Kesehatan-Semestasudah-di-Depan-Mata, akses 15 Maret 2018).

Majelis Ulama Indonesia mengeluarkan Fatwa Dewan Syariah Nasional-Majelis Ulama Indonesia (DSN-MUI) Nomor 98/DSN-MUI/XII/2015 Tentang Pedoman Penyelenggara Jaminan Sosial Kesehatan Syariah, dalam fatwanya membahas Ketentuan Hukum, Akad dan Personalia Hukum, Iuran dan Layanan, Dana Jaminan Sosial Bernilai Negatif, Penempatan dan Pengembangan DJS, Sanksi, dan Perselisihan. ${ }^{15}$

Dasar penetapan fatwa di MUI didasarkan pada al-Qur'an, Hadis, Ijmak dan Qiyas. Keempat hal tersebut merupakan sumber dan dalil hukum syarak yang disepakati oleh Jumhur ulama. Sedangkan yang lainnya, seperti al-Istihsan, al-Istishlah, saddu al-Dzari'ah dan lain sebagainya diperselisihkan keberadaannya sebagai dalil hukum. Secara ringkas dasar dasar

\footnotetext{
${ }^{15}$ Umi Salamah, "Pelaksanaan Fatwa Dewan Syariah Nasional Majelis Ulama Indonesia (DSN MUI) Nomor: 98/DSN-MUI/XII/2015 Tentang Pedoman Penyelenggara Jaminan Sosial Kesehatan Syariah Terhadap BPJS Kesehatan," Doctoral dissertation (2019).
} 
penetapan fatwa MUI sebagai berikut: Pertama, setiap keputusan fatwa harus mempunyai dasar atas kitabullah dan Sunnah Rasul, serta tidak bertentangan dengan kemaslahatan umat. Kedua, jika tidak terdapat dalam Kitabullah dan Sunnah Rasul, keputusan fatwa hendaklah tidak bertentangan dengan ijmak, qiyas yang mu'tabar, dan dalil dalil hukum yang lain, seperti istihsan, masalih mursalah dan sadd az-dzari'ah. Ketiga, sebelum pengambilan keputusan fatwa hendaklah ditinjau pendapat-pendapat para imam madzhab terdahulu, baik yang berhubungan dengan dalil-dalil hukum maupun yang berhubungan dengan dalil yang dipergunakan oleh pihak yang berbeda pendapat. Keempat, pandangan tenaga ahli dalam bidang masalah yang akan diambil keputusan fatwanya dipertimbangkan. ${ }^{16}$

\section{B. METODE PENELITIAN}

Jenis penelitian ini merupakan penelitian deskirptif kuantitatif merupakan jenis penelitian yang bertujuan mendeskripsikan secara sistematis, faktual, dan akurat mengenai fakta dan sifat populasi tertentu. Penelitian deskriptif kuantitatif merupakan usaha sadar dan sistematis untuk memberikan jawaban terhadap suatu masalah dan/atau mendapatkan informasi lebih mendalam dan luas terhadap suatu fenomena dengan menggunakan tahaptahap penelitian dengan pendekatan kuantitatif. ${ }^{17}$

Penelitian ini menggunakan data sekunder yang didapat dari Bapenas yaitu Survey on Financial Inclusion and Access (SOFIA) dengan data terkait peserta BPJS. SOFIA berupaya mengukur dan menggambarkan akses dan penggunaan jasa keuangan oleh semua penduduk dewasa dalam berbagai tingkat pendapatan dan aspek demografi lainnya. Data tersebut dihimpun pada tahun 2017 di empat provinsi (Jawa Timur, Nusa Tenggara Barat, Nusa Tenggara Timur, dan Sulawesi Selatan) yang merepresentasikan tingkat aksesibilitas masyarakat terhadap pemanfaatan teknologi untuk peningkatan layanan BPJS pada Perbankan Syariah.

Analisis data SOFIA hanya menggunakan analisis deskriptif dengan mengukur frekuensi banyaknya keterpilihan alternatif jawaban yang diberikan. Analisis ini di desain untuk mengumpulkan data yang mendeskripsikan karakteristik personal, even maupun situasi. ${ }^{18}$ Analisis deskriptif pada penelitian ini adalah untuk melihat tingkat aksesibilitas masyarakat terhadap pemanfaatan teknologi untuk peningkatan layanan BPJS. Menurut Uma Sekaran analisis deskriptif membantu peneliti untuk memberikan gambaran mengenai karakteristik group dalam situasi tertentu, berpikir secara sistematis mengenai aspek-aspek yang sudah ditentukan, menawarkan ide untuk menggali dan penelitian mendatang. ${ }^{19}$

\section{HASIL DAN PEMBAHASAN}

Dalam pembahasan dibagi menjadi 2 pokok pembahasan, Pembahasan pertama adalah analisis terhadap data dari BAPENAS yakni SOFIA untuk melihat sejauh mana

\footnotetext{
${ }^{16}$ Mashudi, "Konstruksi Hukum Dan Respon Masyarakat Terhadap Sertifikasi Produk Halal," Yogyakarta : Pustaka Pelajar (2015).

${ }^{17}$ A. Muri Yusuf, "Metode Penelitian Kuantitatif, Kualitatif \& Penelitian Gabungan.," Prenada Media Cet.4 (2017). Sons. (2016).

${ }^{18} \mathrm{R}$ Bougie U Sekaran, "Research Methods for Business: A Skill Building Approach,” John Wiley \& ${ }^{19} \mathrm{Ibid}$.
} 
masyarakat Jawa Timur, Nusa Tenggara Barat, Nusa Tenggara Timur, dan Sulawesi Selatan mempunyai BPJS, selanjutnya pembahasan mengenai metode pembayaran asuransi BPJS menggunakan fitur layanan dari perbankan syariah.

\section{Analisis Survey on Financial Inclusion and Access (SOFIA)}

SOFIA memiliki tujuan utama untuk mengukur dan membuat profil tingkat akses dan penggunaan layanan keuangan oleh semua orang dewasa di seluruh rentang pendapatan. SOFIA mengukur tingkat inklusi keuangan baik yang menggunakan jasa keuangan formal maupun informal, menggambarkan lanskap akses produk dan layanan yang digunakan individu, mengidentifikasi pendorong dan hambatan penggunaan produk dan jasa keuangan, dan membantu menentukan kebutuhan akan produk keuangan secara umum dan dengan penekanan khusus pada sektor pertanian, serta kesenjangan antara suply and demand terhadap jasa keuangan yang tersedia. ${ }^{20}$ SOFIA memberikan gambaran mengenai aksesibilitas masyarakat terhadap lembaga keuangan yang dibagi menjadi 3 kategori yakni, akses kepada jasa menabung, pinjaman, pembayaran dan jasa asuransi.

Sampel dalam SOFIA diperoleh 19.634 responden. Aplikasi yang digunakan dalam pengolahan data SOFIA adalah STATA 15. Keunggulan aplikasi STATA adalah memungkinkan pengolahan data sampel yang berjumlah banyak. Karakteristik dari responden SOFIA terdiri dari 8.389 laki laki dan 11.245 perempuan. Dari total Sampel 19.634 responden yang memiliki BPJS 9.806, tidak memiliki BPJS 8.587, tidak memiliki BPJS namun mendapatkan asuransi kesehatan dari perusahaan 1.187, tidak tahu BPJS 54.

Tabel 1. Karakteristik responden berdasarkan Jenis Kelamin Jenis Kelamin Jumlah

\begin{tabular}{lc} 
Laki-Laki & 8.389 \\
Perempuan & 11.245 \\
Total & $\mathbf{1 9 . 6 3 4}$ \\
\hline
\end{tabular}

Sumber : Data diolah, 2020

Tabel 2. Responden BPJS

\begin{tabular}{lc}
\hline BPJS & Jumlah \\
\hline Iya & 9.806 \\
Tidak punya & 8.587 \\
Tidak punya, namun mendapatkan fasilitas asuransi & 1.187 \\
kesehatan dari perusahaan & \\
Tidak tahu & 54 \\
$\quad$ Total & $\mathbf{1 9 . 6 3 4}$ \\
\hline
\end{tabular}

Sumber : Data diolah, 2020

2. Metode Pembayaran Asuransi Menggunakan Fitur Layanan Perbankan Syariah

Potensi pengembangan produk asuransi syariah berbasis syariah salah satunya BPJS di Indonesia masih sangat besar. Cara pembayaran BPJS bisa dilakukan melalui

\footnotetext{
${ }^{20}$ Kementerian PPN/ BAPPENAS, "Survey on Financial Inclusion and Access ( SOFIA )," Survey on Financial Inclusion and Access (2017).
} 
perbankan, dengan elektronik atau langsung. Jika ingin menggunakan uang cash tanpa perantara bank, bisa langsung ke gerai non perbankan seperti minimarket terdekat. Namun, literasi keuangan syariah di Indonesia masih cukup rendah. Oleh sebab itu, perbankan syariah bekerjasama dengan pihak BPJS untuk memberikan pelayanan pembayaran secara online melalui jasa pembayaran perbankan syariah agar nasabah semakin mudah dalam melakukan transaksi pembayaran premi melalui beberapa aplikasi yang ditawarkan.

Tabel 3. Metode Pembayaran yang paling sering digunakan

\begin{tabular}{lrr}
\hline \multicolumn{1}{c}{ Metode Pembayaran } & Jumlah & \multicolumn{1}{c}{ Persentase } \\
\hline Cash & 9.737 & $98.36 \%$ \\
Internet banking & 35 & $0.35 \%$ \\
mobile banking & 41 & $0.41 \%$ \\
ATM & 85 & $0.86 \%$ \\
Credit card & 1 & $0.01 \%$ \\
Total & $\mathbf{9 . 8 9 9}$ & $\mathbf{1 0 0 \%}$ \\
\hline
\end{tabular}

Sumber: Data diolah, 2020

Metode pembayaran yang dilakukan merupakan pembayaran jasa keuangan yaitu salah satunya jasa pembayaran BPJS. dari keseluruhan yang telah diamati pada SOFIA dengan total 9.899 dari responden 19.634 didominasi oleh pembayaran secara cash yaitu 9.737. Hal ini menjadi suatu indikasi masih minimumnya masyarakat di Jawa Timur, Nusa Tenggara Barat, Nusa Tenggara Timur, dan Sulawesi Selatan menggunakan metode pembayaran jasa keuangan,

Produk dan layanan di Indonesia masih dominan disediakan secara pendekatan konvensional. Perusahaan asuransi seperti hanlnya BPJS masih melayani kantor-kantor mereka yang tersebar di seluruh Indonesia. Oleh karena itu masyarakat lebih memilih datang secara langsung untuk membayar BPJS, meskipun sudah diberikan layanan maupun fasilitas pembayaran secara online.

\section{KESIMPULAN}

Inklusi keuangan di empat provinsi (Jawa Timur, Nusa Tenggara Barat, Nusa Tenggara Timur, dan Sulawesi Selatan) bisa dikatakan masih rendah. Dilihat dari pemanfaatan pelayanan pembayaran jasa keuangan masih sedikit yang memanfaatkan dilihat dari objek penelitian yaitu pada pembayaran BPJS. Meskipun sudah diketahui bahwa IKNB syariah tiap tahun meningkat namun inklusi keuangan masih perlu ditingkatkan lagi dengan memberikan edukasi terkait keuangan syariah.

Potensi pengembangan produk asuransi syariah berbasis syariah salah satunya BPJS di Indonesia masih sangat besar. Perbankan syariah bekerjasama dengan pihak BPJS memberikan pelayanan pembayaran secara online melalui jasa pembayaran perbankan syariah agar nasabah semakin mudah dalam melakukan transaksi pembayaran premi melalui beberapa aplikasi yang ditawarkan. 


\section{B. DAFTAR PUSTAKA}

A. Muri Yusuf. "Metode Penelitian Kuantitatif, Kualitatif \& Penelitian Gabungan." Prenada Media Cet.4 (2017).

Akyuwen, Roberto, and Caroline Mangowal. "Komparasi Peningkatan Inklusi Keuangan Dan Indikator Pembangunan Di Indonesia." Modus Vol.30(1), no. 1 (2018).

Asmara Sani, Ageng, Ragil Satria Wicaksana, and Dunyati Ilmiah. "Implikasi Adiba Msme Sebagai Instrumen Channeling Masyarakat Umkm Dalam Menggunakan Layanan Lembaga Keuangan Syariah." Jurnal Tabarru': Islamic Banking and Finance Vol.2, no. 2 (2019).

BAPPENAS, Kementerian PPN/. "Survey on Financial Inclusion and Access ( SOFIA )." Survey on Financial Inclusion and Access (2017).

Hadi, Krishno, Listiana Asworo, and Iradhad Taqwa. "Inovasi Dialogis: Menuju Transformasi Pelayanan Publik Yang Partisipatif (Kajian Sistem Pelayanan Malang Online)." Journal of Government and Civil Society 4, no. 1 (2020).

Itang, Itang. "BPJS Kesehatan Dalam Perspektif Ekonomi Syariah." AHKAM : Jurnal Ilmu Syariah Vol.15, no. 2 (2015).

Laksono, Sasongko Budi. "Analisis Efektivitas Dan Efisiensi Pelaporan Tenaga Kerja Dengan Menggunakan Sistem Manual Dan Sistem Online (Studi Kasus PJS Ketenagakerjaan Cabang Gresik)" (2019).

Lusardi, Annamaria, and Olivia S. Mitchell. "The Economic Importance of Financial Literacy: Theory and Evidence." Journal of Economic Literature Vol.52, no. 1 (2014).

Mashudi. "Konstruksi Hukum Dan Respon Masyarakat Terhadap Sertifikasi Produk Halal." Yogyakarta : Pustaka Pelajar (2015).

OJK. "Roadmap Pengembangan Keuangan Syariah 2017-2019." Otoritas Jasa Keuangan (2017).

Okaro, Celestine Sunday. "Financial Inclusion and Nigerian Economy ( 1990-2015 )." Journal of Policy and Development Studies Vol.10, no. 4 (2016).

Ratnawati, Alifah, Widiyanto bin Mislan Cokrohadisumarto, and Noor Kholis. "Improving the Satisfaction and Loyalty of BPJS Healthcare in Indonesia: A Sharia Perspective." Journal of Islamic Marketing (2020).

Salamah, Umi. "Pelaksanaan Fatwa Dewan Syariah Nasional Majelis Ulama Indonesia (DSN MUI) Nomor: 98/DSN-MUI/XII/2015 Tentang Pedoman Penyelenggara Jaminan Sosial Kesehatan Syariah Terhadap BPJS Kesehatan." Doctoral dissertation (2019).

U Sekaran, R Bougie. "Research Methods for Business: A Skill Building Approach." John Wiley \& Sons. (2016).

Usman, Cahur. "Analisis Pengelolaan BPJS Dalam Perspektif Ekonomi Islam ( Studi Kasus BPJS Kesehatan Makassar )" (2016).

Winarto, Wiebi, Mega Tri Wijayanti, and Lukita Ummahati. "Inovasi Pelayanan Kesehatan Berbasis Elektronik Melalui Sistem Informasi Kesehatan Nasional Online Dan Primary Care BPJS Di Dinas Kesehatan Kota Malang." Prosiding Simposium Nasional (2020). 